NBER WORKING PAPER SERIES

\title{
EXTERNALITIES IN THE CLASSROOM: \\ HOW CHILDREN EXPOSED TO DOMESTIC VIOLENCE AFFECT EVERYONE'S KIDS
}

\author{
Scott E. Carrell \\ Mark L. Hoekstra \\ Working Paper 14246 \\ http://www.nber.org/papers/w14246
}
NATIONAL BUREAU OF ECONOMIC RESEARCH
1050 Massachusetts Avenue
Cambridge, MA 02138

August 2008

Special thanks to Susan Carrell, David Figlio, Caroline Hoxby, Alexis Leon, Jason Lindo, Mel Lucas, Doug Miller, Marianne Page, Nick Sanders, Mel Stephens, and participants at the 2008 NBER Summer Institute for their helpful comments and suggestions. The views expressed herein are those of the author(s) and do not necessarily reflect the views of the National Bureau of Economic Research.

NBER working papers are circulated for discussion and comment purposes. They have not been peerreviewed or been subject to the review by the NBER Board of Directors that accompanies official NBER publications.

(C) 2008 by Scott E. Carrell and Mark L. Hoekstra. All rights reserved. Short sections of text, not to exceed two paragraphs, may be quoted without explicit permission provided that full credit, including (C) notice, is given to the source. 
Externalities in the Classroom: How Children Exposed to Domestic Violence Affect Everyone's Kids

Scott E. Carrell and Mark L. Hoekstra

NBER Working Paper No. 14246

August 2008

JEL No. I2,J24

\begin{abstract}
$\underline{\text { ABSTRACT }}$
It is estimated that between ten and twenty percent of children in the United States are exposed to domestic violence annually. While much is known about the impact of domestic violence and other family problems on children within the home, little is known regarding the extent to which these problems spill over to children outside the family. The widespread perception among parents and school officials is that these externalities are significant, though measuring them is difficult due to data and methodological limitations. We estimate the negative spillovers caused by children from troubled families by exploiting a unique data set in which children's school records are matched to domestic violence cases filed by their parent. To overcome selection bias, we identify the effects using the idiosyncratic variation in peers from troubled families within the same school and grade over time. We find that children from troubled families significantly decrease their peers' reading and math test scores and significantly increase misbehavior of others in the classroom. The effects are heterogeneous across income, race, and gender and appear to work primarily through troubled boys. The results are robust to within-sibling differences and we find no evidence that non-random selection is driving the results.
\end{abstract}

Scott E. Carrell

Department of Economics

University of California, Davis

One Shields Avenue

Davis, CA 95616

and NBER

secarrell@ucdavis.edu

Mark L. Hoekstra

Department of Economics

University of Pittsburgh

4714 W. W. Posvar Hall

Pittsburgh, PA, 15260

markhoek@pitt.edu 


\section{Introduction}

It is estimated that between ten and twenty percent of children in the United States are exposed to domestic violence annually (Carlson, 2008). Research in the psychology literature indicates that these children suffer from a number of social and emotional problems including aggressive behavior, depression, anxiety, decreased social competence, and diminished academic performance (Edleson, 1999; Wolfe, et al., 2003; Fantuzzo \& Mohr, 1999; Koenen, et al., 2003). There is also widespread belief among parents and school officials that troubled children such as these negatively affect learning in the classroom. For example, a nationally representative survey found that 85 percent of teachers and 73 percent of parents said that the "school experience of most students suffers at the expense of a few chronic offenders" (Public Agenda, 2004). ${ }^{1}$

Understanding the significance of these negative classroom spillovers is central to resolving educational policy debates on issues such as school choice, tracking, and affirmative action. However, credibly estimating peer effects caused by troubled children has been difficult due to both data and methodological limitations. As a practical matter, most data sets do not allow researchers to identify exogenously troubled children. For example, it is difficult to determine if a disruptive child causes his classmates to misbehave or if his classmates cause him to be disruptive. In addition, troubled children are likely to self-select into the same schools and grades as other disadvantaged children. Consequently, one must rule out the possibility that the disruptive student and his classmates misbehave due to common unobserved attributes.

\footnotetext{
${ }^{1}$ In addition, parents cited undisciplined and disruptive students ( 71 percent) and lack of parental involvement (68 percent) as the top two problems facing our nations school system in the National Public Radio/ Kaiser Family Foundation/ Kennedy School of Government Education Survey (NPR, 1999).
} 
We overcome these problems by utilizing a unique data set in which children's outcomes on academic achievement and discipline are linked to domestic violence cases filed by their parent. Because these children are troubled for family reasons exogenous to their peers (i.e., a child's peers do not cause domestic violence in the household), we can estimate their impact on other students free from the reflection problem. Furthermore, the panel nature of our data set allows us to include school-by-grade fixed effects and school-by-grade-specific linear time trends to control for the nonrandom selection of individuals into schools. Thus, our identification strategy relies on idiosyncratic shocks in the proportion of peers from families with a history of domestic violence within school-grade cohorts over time.

We find that an increase in the number of children from troubled families, as measured by family domestic violence, within a school-grade cohort causes a statistically significant reduction in peer student math and reading test scores and significant increases in peer disciplinary infractions and suspensions. Troubled boys primarily drive the negative spillovers that are quite heterogeneous across income, gender, and race. For example, we estimate that adding one more troubled boy peer to a classroom of 20 students reduces boys' student test scores by nearly two percentile points (one-fifteenth of a standard deviation) and increases the probability that boys commit a disciplinary infraction by 17 percent (4.4 percentage points).

These findings are robust to within family comparisons (i.e., including sibling fixed effects) and the inclusion of cohort-level controls for race, gender, income, and subsidized lunch. We also test for potential nonrandom selection into school-grade-year cohorts by performing several falsification exercises. We find no evidence that cohort size or exogenous family characteristics such as race, gender, and household income are 
correlated with the proportion of peers exposed to domestic violence after conditioning on our full set of controls.

These results have important implications for both education and social policy. First, they suggest that policies that change a child's exposure to classmates from troubled families will have important consequences for his educational outcomes. In addition, the results also help provide a more complete measure of the social costs of family conflict.

\section{Data}

We use a confidential student-level data set provided by the School Board of Alachua County in the state of Florida. This data set consists of observations of students in the 3rd through 5th grades from 22 public elementary schools for the academic years 1995-96 through 2002-2003. The Alachua County School District is large relative to school districts nationwide; in the 2000-2001 school year it was the 194th largest school district among the more than 16,000 districts nationwide. Table 1 shows summary statistics for our data. The student population in our sample is approximately 55 percent white, 38 percent black, 3.5 percent Hispanic, 2.5 percent Asian, and 1 percent mixed. Fifty-three percent of students were eligible for subsidized lunches. The test score data consist of a panel of norm-referenced reading and mathematics exam scores from the Iowa Test of Basic Skills and the Stanford 9 exams. Reported scores reflect the percentile ranking on the national test relative to all test-takers nationwide. For all academic outcome specifications we report results using a composite score, which is calculated by taking the average of the math and reading scores. ${ }^{2}$

\footnotetext{
${ }^{2}$ Using a composite score has the advantage of increasing precision by reducing measurement error in the dependent variable (West and Peterson, 2006). When we estimate our effects separately for reading and math scores the peer coefficients are not statistically distinguishable from each other and generally vary by no more than $20 \%$. For example, the coefficient corresponding to the result for the peer variable in Table 2 is
} 
Yearly disciplinary records are also observed for every student in our sample.

Disciplinary records for students are recorded by incident type and date in the Student Discipline System. For elementary school students, "incidents that are very serious or require intervention from the principal or other designated administrator" are reported in the system (SBAC, 1997). We also observe information on each student's race, gender, school lunch status, and median zip code income.

The domestic violence data used in this study were gathered from public records information at the Alachua County Courthouse and include the date filed and the names and addresses of individuals involved in domestic violence cases filed in civil court in Alachua County between January 1, 1993 and March 12, 2003. These domestic violence cases are initiated when one family member (e.g., the mother) petitions the court for a temporary injunction for protection against another member of the family (e.g., the father or boyfriend). ${ }^{3}$ Students were linked to cases in which the petitioner's first and last name and first three digits of his or her residential address matched the parent name and student's residential address in the annual school record. In that way, we were able to identify the set of students within a school-grade-year cohort who come from families with a history of domestic violence. In total, 4.6 percent of the children in the sample were linked to a domestic violence case filed by a parent, equally split between boys and girls. Sixty-one percent of these children were black while 85 percent were eligible for subsidized school lunches.

14.20 for reading scores and 14.39 for math scores. Separate results for math and reading scores for all of the specifications reported in the paper are available upon request from the authors.

${ }^{3}$ The judge then decides whether to issue a 15-day injunction against the alleged offending party and sets a date for a hearing to decide on further action. If the request for a temporary injunction is denied, the petitioner is typically given opportunity to provide more evidence that an injunction is necessary. 
We examine how peers affect student performance and behavior across four different outcome variables from our school data set. The primary academic outcome is a composite (average) score on the annual mathematics and reading scores on the Iowa Test of Basic Skills or Stanford 9 examinations. We also examine three behavioral outcomes from the disciplinary records, including the probability the student was involved in a disciplinary incident, the total number of disciplinary incidents per student, and the probability the student was suspended.

\section{Measuring Externalities in the Classroom: Overcoming Selection Bias and the Reflection Problem}

Our approach to measuring negative externalities in the classroom is to examine the impact of children from troubled families on their peers. This type of peer effect is commonly called the "bad apple" model of peer effects (Hoxby \& Weingarth, 2006). However, measuring such effects has proven difficult for reasons that are well documented in the peer effects literature. First, because child and peer outcomes are determined simultaneously, it is difficult to distinguish the effect that the group has on the individual from the effect the individual has on the group. This is commonly called the reflection problem (Manski, 1993). Second, when individuals self-select into peer groups, it is impossible to determine whether the achievement is a causal effect of the peers or simply the reason the individuals joined the peer group (Hoxby, 2002). Finally, common shocks or correlated effects confound peer effects estimates because it often difficult to separate the peer effect from other potentially shared treatment effects (Lyle, 2007).

Both the simultaneity and common shock problems are best resolved by finding a suitable (pre-treatment) instrument for peer behavior that is exogenous with respect to the 
stochastic error component of the dependent variable. The most common strategy in the primary and secondary education peer effects literature ${ }^{4}$ has been to use lagged peer achievement as an instrument for current achievement. While this strategy is presumably the consequence of data constraints, the problem with using lagged peer achievement is that it may not be exogenous to contemporaneous achievement. ${ }^{5}$ Additionally, these studies typically identify peer effects from very small changes in average peer (lagged) test scores without knowing why some peers' test scores are higher than others. In contrast, our approach uses historical family problems as an exogenous source of variation in peer quality. That is, we assume there is no potential feedback loop where a student's peers cause the domestic violence in the household. This assumption appears reasonable; none of the primary determinants of domestic violence analyzed by Jewkes (2002) can plausibly be linked to one's own elementary school child or her peers. ${ }^{6}$

The self-selection problem has been handled in the peer effects literature in two ways. The first strategy, primarily used in the higher education literature, is to exploit the random assignment of individuals to peer groups (Boozer \& Cacciola, 2001; Foster, 2006; Sacerdote, 2001; Zimmerman, 2003; Lyle, 2007; Stinebrickner \& Stinebrickner, 2006; Kremer \& Levy, 2003; Carrell, Fullerton, \& West, 2008). As this rarely occurs in

\footnotetext{
${ }^{4}$ Studies examining classroom peer effects in primary and secondary education include see: Angrist \& Lang (2004), Hoxby \& Weingarth (2006), Hanushek, et al. (2003), Boozer \& Cacciola (2001), Vigdor \& Nechyba (forthcoming), Burke \& Sass (2004), Betts \& Zau (2004), Lavy, Paserman, and Schlosser (2007), Lavy \& Schlosser (2007) and Figlio (2007).

5 This is because many of the peers in an individual's current peer group were also likely to be peers in the previous period(s). Hence, previous peer achievement is not exogenous to individual current achievement due to the cumulative nature of the education production function.

${ }^{6}$ Jewkes (2002) notes that the causes of domestic violence are complex, but cites alcohol, power, financial distress, and sexual identity as the primary determinants.
} 
primary and secondary education, ${ }^{7}$ a second approach has been to exploit the variation in cohort composition across time within a given school. ${ }^{8}$ This is accomplished by using large administrative panel data sets while employing a series of fixed effects models.

To overcome self-selection, we follow this latter approach by controlling for a full set of individual and group characteristics as well as school-by-grade fixed effects, year effects, and school-by-grade-specific linear time trends. Thus, our identification strategy relies on idiosyncratic shocks in the proportion of peers from families with a history of domestic violence across grade cohorts within schools over time. ${ }^{9}$ Of critical importance to this strategy is that students are not systematically placed into or pulled out of a particular grade cohort within a school depending on the domestic violence status of the student or their peers. For example, if parents with a high value of education were to pull their children out of a cohort with a particularly high proportion of peers from troubled families, such non-random selection would cause us to erroneously attribute lower performance to the presence of the troubled peers. To formally test for this and other types of self-selection, in the next section we regress exogenous student characteristics on the proportion of peers in the school-grade cohort with a history of family violence. We find no evidence that cohort size or exogenous family characteristics such as race, gender, and household income are correlated with the proportion of peers exposed to domestic violence after conditioning on our full set of controls.

\footnotetext{
${ }^{7}$ The one exception is Project STAR.

${ }^{8}$ See Hoxby, 2000b, Hoxby \& Weingarth, 2006; Vigdor \& Nechyba, 2004; Betts \& Zau, 2004; Burke \& Sass, 2004; Hanushek, et al., 2003; Lefgren, 2004; Carrell, Malmstrom, \& West, 2008)

${ }^{9}$ Our identification strategy is similar to that used by Hoxby (2000a and 2000b) in identifying class size and peer effects using idiosyncratic variation in the population.
} 
Figure 1 below plots the school-by-year proportion of peers from families with domestic violence for third graders from 1996 through 2003 in Alachua County. ${ }^{10}$

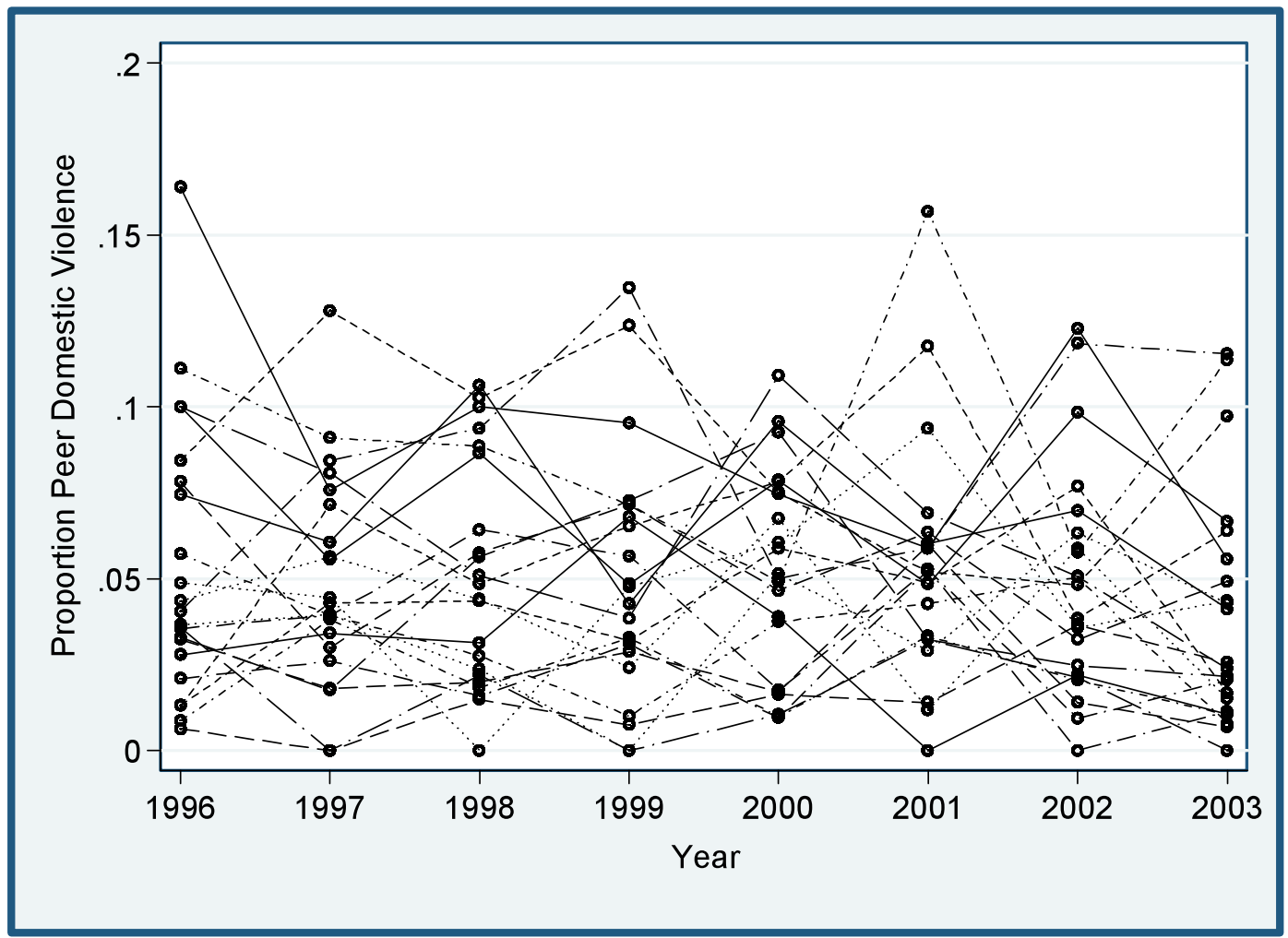

Figure 1: Proportion of $3^{\text {rd }}$ Grade Peers from Families with Domestic Violence from 1996 to 2003 by School

A visual inspection of the figure reveals there is substantial year-to-year variation within schools in the proportion of peers from families with domestic violence. In addition, every school has at least one $3^{\text {rd }}$ grade cohort with a student from a family with a history of domestic violence. Finally, no particular school consistently has the highest or lowest proportion of students from families with a history of domestic violence. In summary, Figure 1 indicates that no school in our sample is immune to having students from families with a history of domestic violence, nor does any particular school appear to be a "magnet" for children from troubled families.

${ }^{10}$ Figures for fourth and fifth grade cohorts are shown at the end of the text. 


\section{Methods and Results}

\section{Methods}

We first measure peer effects using the traditional reduced form linear-in-means model where we regress individual outcomes on a peer family violence. Specifically, we estimate the following equation for our four individual student outcomes:

$$
y_{i s g t}=\phi_{0}+\phi_{1} \frac{\sum_{k \neq i} D V_{k s g t}}{n_{s g t}-1}+\beta X_{i s g t}+\lambda_{s g}+\sigma_{t}+\phi_{s g} t+\varepsilon_{i s g t},
$$

where $y_{\text {isgt }}$ is the outcome variable for individual $i$ in school $s$ grade $g$, and in year $t$.

$\frac{\sum_{k \neq i} X_{k s g t}}{n_{s g t}-1}$ is the proportion of peers in the school grade cohort from families with domestic violence, except individual $i$. We measure peer domestic violence at the cohort level as opposed to the classroom level due to potential nonrandom selection of students to classrooms within a school and grade (Hoxby, 2000b). $X_{\text {isgt }}$ is a vector of individual $i$ 's specific (pre-treatment) characteristics, including own family violence, race, gender, subsidized lunch, and median zip code income. $\lambda_{s g}, \sigma_{t}$, and $\phi_{s g}$ are school-grade fixed effects, year fixed effects, and school-grade specific linear time trends. The linear time trend is included to account for any changes in the neighborhood or school that are specific to that school-grade. In some specifications we also control for a full set of cohort specific variables such as mean race, gender, subsidized lunch, and zip code income. $\varepsilon_{i s g t}$ is the error term. Given the potential for error correlation across individuals who attended school with the same classmates in the $3^{\text {rd }}$ through $5^{\text {th }}$ grades, we correct all standard errors to reflect clustering at the school by grade-cohort level (i.e., the set of student who attended $3^{\text {rd }}$ through $5^{\text {th }}$ grade in the same school). 


\section{Mean Effects}

We estimate various specifications of equation (1) using ordinary least squares (OLS) for student outcomes, with results shown in Table 2. Specification 1 shows results for composite math and reading test score and Specifications 2 through 4 show results for disciplinary outcomes. The coefficients on own family violence are statistically significant and of the expected sign in all four specifications. These results indicate that children from families with a history of domestic violence have significantly lower reading and math scores $(-3.85)$ and are more likely to be troubled as measured by the probability of committing a disciplinary infraction (0.05), the number of infractions (0.31), and the probability of being suspended (0.04).

The estimated coefficient on the peer family violence variable in Specification 1 is negative and statistically significant $(-13.42)$ at the 0.10 -level, indicating that troubled peers have a significant negative effect on (peer) student reading and math test scores. The magnitude of the effect implies that adding one additional troubled student to a classroom of twenty students (roughly a one standard deviation increase) results in over a two-thirds of a percentage point (roughly one-fortieth of a standard deviation) decrease in student reading and math test scores.

For Specifications 2 and 3, the estimated coefficients on the peer family violence variable are positive and significant for both the probability of committing a disciplinary infraction (0.22) and the number of infractions (1.80). These results indicate that troubled peers significantly increase misbehavior of other students in the classroom. For Specification 2, the model estimates that one more troubled peer added to a cohort has the 
net effect of "producing" 0.27 additional students who commit a disciplinary infraction. ${ }^{11}$ Following Glaeser, Sacerdote \& Scheinkman (2003) and Carrell, Malmstrom \& West (2008), we believe this estimate to be the first-order effect and a lower bound of the total peer influence. That is, in full equilibrium, the creation of new students who commit disciplinary infractions is likely to create additional infractions, implying the existence of an endogenous "social multiplier". 12

Finally, Specification 4 shows results for the probability of a student being suspended. The peer family violence variable has the expected positive sign $(0.13)$, but is outside conventional levels of statistical significance $(\mathrm{p}=0.18)$.

Results from Table 2 provide evidence that children from troubled families perform significantly worse on standardized reading and mathematics tests and are much more likely to commit disciplinary infractions and be suspended. We also find robust evidence that these children produce negative externalities within the classroom for reading and math test scores and disciplinary outcomes.

\section{Differential Effects by Family Income, Race, and Gender}

Having found that troubled families impose statistically significant externalities on classroom peers on average, we next explore the heterogeneity of these effects across a student's family income, race, and gender. Results are presented in Tables 3 and 4.

In Table 3, results show that peers from troubled families differentially affect children by income, as measured by subsidized lunch status. Specifically, we find that troubled peers have a large and statistically significant negative effect on higher income children's

\footnotetext{
${ }^{11}$ This effect was calculated by adding the coefficients on the own and peer family violence variables.

${ }^{12}$ Empirical estimation of the social multiplier is discussed extensively in Glaeser, Sacerdote and Scheinkman (2003) and using their methodologies we found social multipliers ranging between 4.52 and 7.23 for our various outcomes.
} 
math and reading achievement $(-24.85)$ and a small and statistically insignificant effect on low-income children (-7.43). However, we find the opposite to be true for disciplinary outcomes. The presence of troubled peers significantly increases misbehavior of low-income children, but does not increase the disciplinary problems of higher-income children.

Results examining the differential effects of peers from troubled families by race and gender are shown in Table 4. Results in Specification 1 show relatively large negative and statistically significant test score effect for white boys ${ }^{13}(-31.64)$ and statistically insignificant results for black boys (-17.56), black girls (-9.02), and white girls (4.30). ${ }^{14}$ The magnitudes of the effects imply that adding one additional troubled peer to a classroom of twenty students reduces white boys' reading and math scores by 1.58 percentile points and black boys' reading and math scores by 0.88 percentile points.

Specifications 2 through 4 show results for disciplinary outcomes. We find that troubled peers increase disciplinary problems for all subgroups except for white girls. The effects are largest for black girls. For Specification 2, the total estimated effect of family domestic violence on disciplinary infractions is substantial, with one more troubled peer added to a classroom of twenty students increases the probability that a black girl commits a disciplinary infraction by 2.2 percentage points (10 percent).

In summary, results from Tables 3 and 4 provide two interesting findings. First, children from troubled families differentially affect higher income and boys' academic

\footnotetext{
${ }^{13}$ Our sample is predominately two races: black (56-percent) and white (36-percent). The small population of Hispanic (4-percent) and Asian (2-percent) students are grouped with the white category.

${ }^{14}$ We cannot reject that the effects on black boys and black girls are statistically different from white boys.
} 
outcomes. ${ }^{15}$ Second, children from troubled families differentially increase misbehavior in the classroom for lower income students, boys, and black girls.

\section{Effects by the Gender of the Troubled Peers}

Having found evidence that the negative spillovers caused by troubled families vary with the income, gender, and race of the classroom peers, we next look to see if they differ by the gender of the children causing the negative externalities. That is, we examine whether troubled boys differentially affect their peers relative to troubled girls. Table 5 shows results from this analysis, where we estimate separate effects for boys and girls. Specification 1 shows results for the academic outcome and Specifications 2-4 show results for disciplinary outcomes. Across all outcome variables, the negative peer effects appear to be driven primarily by the troubled boys in the cohort and these effects are largest on other boys in the classroom. In all specifications the coefficients for boys on the boy peer variable are statistically significant and of the expected sign, while the coefficients for girls and the girl peer variables are smaller and statistically insignificant. For Specification 1, the coefficient for boys on boy peer family violence (-38.34) implies that adding one additional troubled boy peer to a classroom of 20 students decreases boy test scores by nearly two percentile points. For Specification 2, the model predicts that adding one additional troubled boy peer to a classroom of 20 students increases the probability that a boy will commit a disciplinary infraction by 4.4 percentage points (17 percent).

\footnotetext{
${ }^{15}$ In results not shown we find that the proportion of black girls from troubled families within a cohort has a statistically significant negative effect on the achievement of black girls, though again we find no effect of any group of troubled children on the achievement of white girls.
} 


\section{Robustness Checks}

Table 6 presents results of three robustness checks of the results presented in Table 5 . As discussed previously, a major concern when comparing school-by-grade cohorts over time is that parents with a high value of education may pull their children out of a cohort with a particularly high proportion of peers from troubled families. Such non-random selection would cause us to erroneously attribute lower performance to the presence of troubled peers. Noting that some parents may be more likely to put their children in private schools ${ }^{16}$ or move to a different school zone, our first robustness check focuses only on children with siblings. The intuition behind this test is that parents may be less likely to pull one child out of the school due to a particularly bad cohort when that child has a sibling in the same school. These results are shown in Section A of Table 5 and are qualitatively and quantitatively similar to the results for the full sample.

One might also be concerned that the effects shown earlier are due to certain families that do not manage to select out of particularly bad cohorts. To check this, we use only the within-family variation in peer family violence by adding sibling fixed effects to the model. ${ }^{17}$ Results in Section B of Table 6 show that, even within families, troubled boy peers have a statistically significant negative effect on other boy reading and math scores (-26.90) and a significant positive effect on the probability of a disciplinary infraction (0.50), the number of student disciplinary infractions (4.85), and the probability of being suspended (0.40). These within-family estimates are roughly two-thirds the magnitude of the estimates for the full sample although they are not statistically different. This

\footnotetext{
${ }^{16}$ Approximately $10 \%$ of children in Alachua County attend private schools.

${ }^{17}$ One disadvantage of this model is the possibility that classroom peer effects have feedback effects within a family. That is, peer effects that affect one sibling also affect the other sibling through interaction within the home. Such feedback effects would likely bias the sibling fixed effects estimates toward zero.
} 
provides strong evidence that the effects found are not a consequence of families with negative unobserved attributes selecting into school-grade-year cohorts with an idiosyncratically high number of children from troubled families.

As a final robustness check, Section $\mathrm{C}$ shows results while controlling for a full set of cohort-level variables including: race, gender, subsidized lunch, and median zip code income. These cohort-level variables are added to control for any potential within school-grade changes in cohort quality not captured by our full set of individual controls, fixed effects, and time trends. In addition, this allows us to examine whether the presence of children exposed to domestic violence is merely a proxy for other peer characteristics such as gender or family income. Results from these specifications are qualitatively similar to our full-sample results, with boy troubled peers having a significant negative effect on boys' reading and math test scores (-37.08) and significant positive effects on boys' disciplinary outcomes.

\section{$\underline{\text { Falsification Tests }}$}

To further test for non-random selection of students into or out of particular schoolgrade-year cohorts, we perform a series of falsification tests where we regress exogenous student characteristics (cohort size, subsidized lunch status, log median zip code income, race, and gender) on the peer family violence variables. Zero correlation between these exogenous student variables and the peer family violence variables is expected in the absence of self-selection.

The results are presented in Table 7 and imply that the effect of peer family violence on cohort size, income, race, and gender are both economically and statistically insignificant. For example, the results from Specification 1 imply that a one standard deviation increase in the proportion of troubled boy peers is associated with a 0.17 - 
student decrease in cohort size (87.30 to 87.13). Similarly, for Specification 5 the estimates predict that a one standard deviation increase in the proportion of troubled boy peers is associated with a $0.21 \%(\$ 90)$ decrease in the annual zip code income of the cohort. Collectively, these results provide evidence that the results presented earlier are not due to non-random selection into or out of school-grade-year cohorts.

\section{Conclusion}

Measuring the extent to which family problems such as domestic violence spill over to children outside the home has thus far been difficult due to data constraints and methodological problems. We estimate these externalities by examining the extent to which children from troubled families — as signaled by the presence of domestic violence within the family—negatively affect their classroom peers. To do so, we utilize a unique dataset in which children's school records are matched to domestic violence cases filed by their parent. Because these children are troubled for a reason exogenous to their peers, we can estimate these negative spillovers free from the reflection problem that has been difficult to overcome in the previous peer effects literature. In addition, the panel nature of our data allows us to control for school-by-grade fixed effects and school-by grade-specific linear time trends and thus identify the externalities by comparing cohorts with idiosyncratically high proportions of troubled peers to cohorts within the same school and grade with idiosyncratically low proportions of troubled peers.

We find that children from troubled families significantly decrease their peers' reading and math test scores and significantly increase misbehavior by others in the classroom. Specifically, we estimate that one more troubled peer in a classroom of 20 students reduces student test scores by 0.67 percentile points and increases the number of student disciplinary infractions committed by students by 16 percent. This implies that 
given Carlson's (2008) estimate that roughly 15 percent of children are exposed to domestic violence every year, the total per-student external marginal damage caused by these troubled families is a 2-point reduction in test scores and a 48 percent increase in the number of disciplinary infractions. We also find that these externalities vary across family income, race, and gender and appear to be caused primarily by boys from troubled families.

We conclude that the results are not a consequence of non-random selection into or out of school-by-grade-by-year cohorts since neither cohort size nor cohort composition (as measured by race, gender, and household income) is affected by the proportion of troubled peers. Similarly, the results are unaffected by the inclusion of controls for other peer characteristics. Finally, estimates are similar when using only within-family variation in exposure to troubled children. This helps rule out the possibility that the results are being driven by the negative unobserved attributes of families whose children are exposed to an idiosyncratically high proportion of troubled peers.

These results have significant implications for both education and social policy. Our results suggest that the extent to which school policies such as school choice or tracking increase a group's exposure to children from troubled families, student performance in school will be affected in a negative way. Furthermore, our results are also relevant for social policy in that they suggest that the social costs of troubled families extend beyond the private costs born by the children in the home. Consequently, any intervention that reduces family conflict may well have larger positive effects than previously thought. 


\section{Bibliography}

Angrist, J.D. \& Lang, K. (2004). Does School Integration Generate Peer Effects? Evidence from Boston's Metco Program, The American Economic Review, Vol. 94, No. 5 (Dec., 2004), pp. 1613-1634

Betts J.R. \& Zau A. (2004). Peer Groups and Academic Achievement: Panel Evidence from Administrative Data. Unpublished Manuscript.

Boozer, M.A. \& Cacciola, S.E. (2001). Inside the 'Black Box' of Project STAR: Estimation of Peer Effects Using Experimental Data. Unpublished manuscript.

Burke, M.A. \& Sass, T.R. (2004). Classroom Peer Effects and Student Achievement. Presented at the American Economic Association Annual Meetings, Jan 2005.

Carlson, B.E., (2000). Children Exposed to Intimate Partner Violence: Research Findings and Implications for Intervention, Trauma, Violence, \& Abuse, 1; 321-342.

Carrell, S.E. \& Carrell, S.A. (2006). Do Lower Student To Counselor Ratios Reduce School Disciplinary Problems? Contributions to Economic Analysis \& Policy: Vol. 5: No. 1, Article 11

Carrell, S.E., Fullerton, R.L., \& West, J.E., (2008). Does Your Cohort Matter? Measuring Peer Effects in College Achievement, Working Paper.

Carrell, S.E., Malmstrom, F.V., \& West, J.E., (2008). Peer Effects in Academic Cheating, Journal of Human Resources, Volume XLIII, Number 1, Winter 2008, 173 207.

Edleson, J.L., (1999). Children's Witnessing of Adult Domestic Violence, Journal of Interpersonal Violence, Vol. 14, No. 8, 839-870.

Fantuzzo, J.W. \& Mohr, W.K., (1999). Prevalence and Effects of Child Exposure to Domestic Violence, The Future of Children, Vol. 9, No. 3, Domestic Violence and Children, pp. 21-32

Figlio, D.N., (2007). Boys Named Sue: Disruptive Children and Their Peers, Education Finance and Policy, Fall 2007, Vol. 2, No. 4, Pages 376-394.

Foster, Gigi, (2006). It's not your peers, and it's not your friends: some progress towards understanding educational peer effects, Journal of Public Economics, Vol 90, Issue (8-9), pp 1455-1475.

Glaeser, E.L., Sacerdote, B.L., and Scheinkman, J.A., (2003). The Social Multiplier. Journal of the European Economic Association, 1, 345 - 353 
Guryan J., Kroft, K., and Notowidigdo, M. (2007). Peer Effects in the Workplace: Evidence From Random Assignment in Professional Golf, NBER Working Paper 13422

Hanushek, E.A., Kain, J.F., Markham, J.M. \& Rivkin, S.G. (2003). Does Peer Ability Affect Student Achievement? Journal of Applied Econometrics, 18, 527-544.

Hoxby, C.M. (2000a). The Effects of Class Size on Student Achievement: New Evidence From Population Variation, Quarterly Journal of Economics, Vol 15, Issue 4, 1239-1285.

Hoxby, C.M. (2000b). Peer Effects in the Classroom: Learning from Gender and Race Variation, NBER Working Paper 7867.

Hoxby, C.M. (2002). The Power of Peers, Education Next, Vol 2, No 2, 57-63.

Hoxby, C.M. and Weingarth, G., (2006). Taking Race Out of the Equation: School Reassignment and the Structure of Peer Effects. Working Paper.

Jewkes, R. (2002). Intimate partner violence: causes and prevention, The Lancet, Volume 359: 1423-29

Kitzmann, K.M., Gaylord, N.K., Holt, A.R., \& Kenny, E.D., (2003). Child Witnesses to Domestic Violence: A Meta-Analytic Review, Journal of Consulting and Clinical Psychology, Vol. 71, No. 2, 339-352.

Koenen, K.C., Moffitt, T.E., Caspi, A., Taylor, A., and Purcell, S., (2003) Domestic violence is associated with environmental suppression of IQ in young children, Development and Psychopathology (2003), 15: 297-311

Kolbo, J.R., Blakely, E.H., and Engleman, D. (1996). Children Who Witness Domestic Violence: A Review of Empirical Literature. Journal of Interpersonal Violence, Vol. 11, No. 2, 281-293

Kremer, Michael, and Levy, Dan M. (2003). Peer Effects and Alcohol Use Among College Students. NBER Working Paper 9876.

Lavy, V., Paserman, M.D, \& Schlosser, A. (2007). Inside the Black of Box of Ability Peer Effects: Evidence from Variation in High and Low Achievers in the Classroom, Working Paper.

Lavy, V. \& Schlosser, A. (2007). Mechanisms and Impacts of Gender Peer Effects at School, NBER Working Paper 13292.

Lefgren, Lars. Educational Peer Effects and the Chicago Public Schools. Journal of Urban Economics, 56(2): 169-191, 2004. 
Lyle, David S. (2007). Estimating and Interpreting Peer and Role Model Effects from Randomly Assigned Social Groups at West Point, Review of Economics and Statistics, Volume 89, Issue, 289-299, 2007.

Manski, C.F. (1993). Identification and Endogenous Social Effects: The Reflection Problem. Review of Economic Studies, 60, 531-542.

Moffitt, Robert A. (2001). Policy Interventions, Low-Level Equilibria, and Social Interactions. In Social Dynamics, edited by Seven N. Durlauf and H. Peyton Young. Brookings Institution Press, Washington D.C.

National Institute of Mental Health (NIMH), 2001. Blueprint for Change: Research on Child and Adolescent Mental Health. Department of Health and Human Services, Washington, D.C.

National Public Radio (NPR)/ Kaiser Family Foundation/ Kennedy School of Government (1999). Survey on Education, Accessed on April 23, 2008 at: http://www.npr.org/programs/specials/poll/education/education.front.html

Public Agenda (2004). Education : Teaching Interrupted: Do Discipline Policies in Today's Public Schools Foster the Common Good? Accessed on April 23, 2008 at: http://www.publicagenda.org/research/research_reports details.cfm?list=3

School Board of Alachua County (SBAC). 1997. Student Discipline System. Reference Manual. 4 August 1997.

Stinebrickner, R. \& Stinebrickner, T.R. (2006). What can be learned about peer effects using college roomates? Evidence from new survey data and students form disadvantaged backgrounds. Journal of Public Economics, 90, 1435-1454.

Vigdor, J. \& Nechyba, T. (2004). Peer Effects in North Carolina Public Schools. Forthcoming, Schools and the Equal Opportunity Problem, P.E. Peterson and L. Woessmann, eds., MIT Press.

West, Martin, and Paul Peterson. (2006). The Efficacy of Choice Threats within School Accountability Systems: Results from Legislatively Induced Experiments, Economic Journal, 116 (March): C46 - C62

Wolfe, D.A., Crooks, C.V., Lee, V., McIntyre-Smith, A., \& Jaffe, P.G., (2003). The Effects of Children's Exposure to Domestic Violence: A Meta-Analysis and Critique, Clinical Child and Family Psychology Review, Volume 6, Number 3, 171-187

Zimmerman, D.J. (2003). Peer Effects in Academic Outcomes: Evidence From a Natural Experiment. The Review of Economics and Statistics, 85, 1, 9-23 


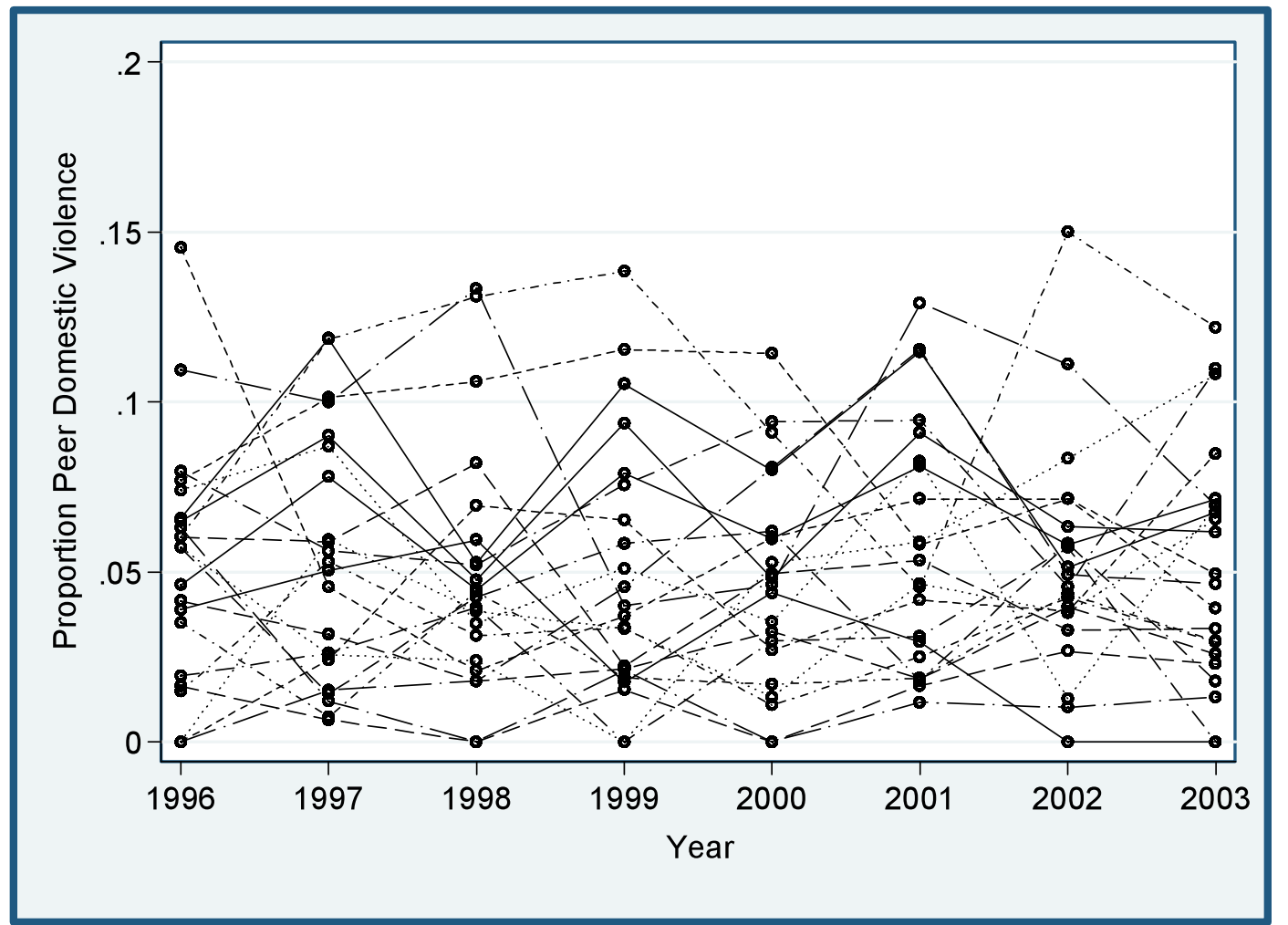

Figure 2: $4^{\text {th }}$ Grade Peers from Families with Domestic Violence from 1996 to 2003 by School 


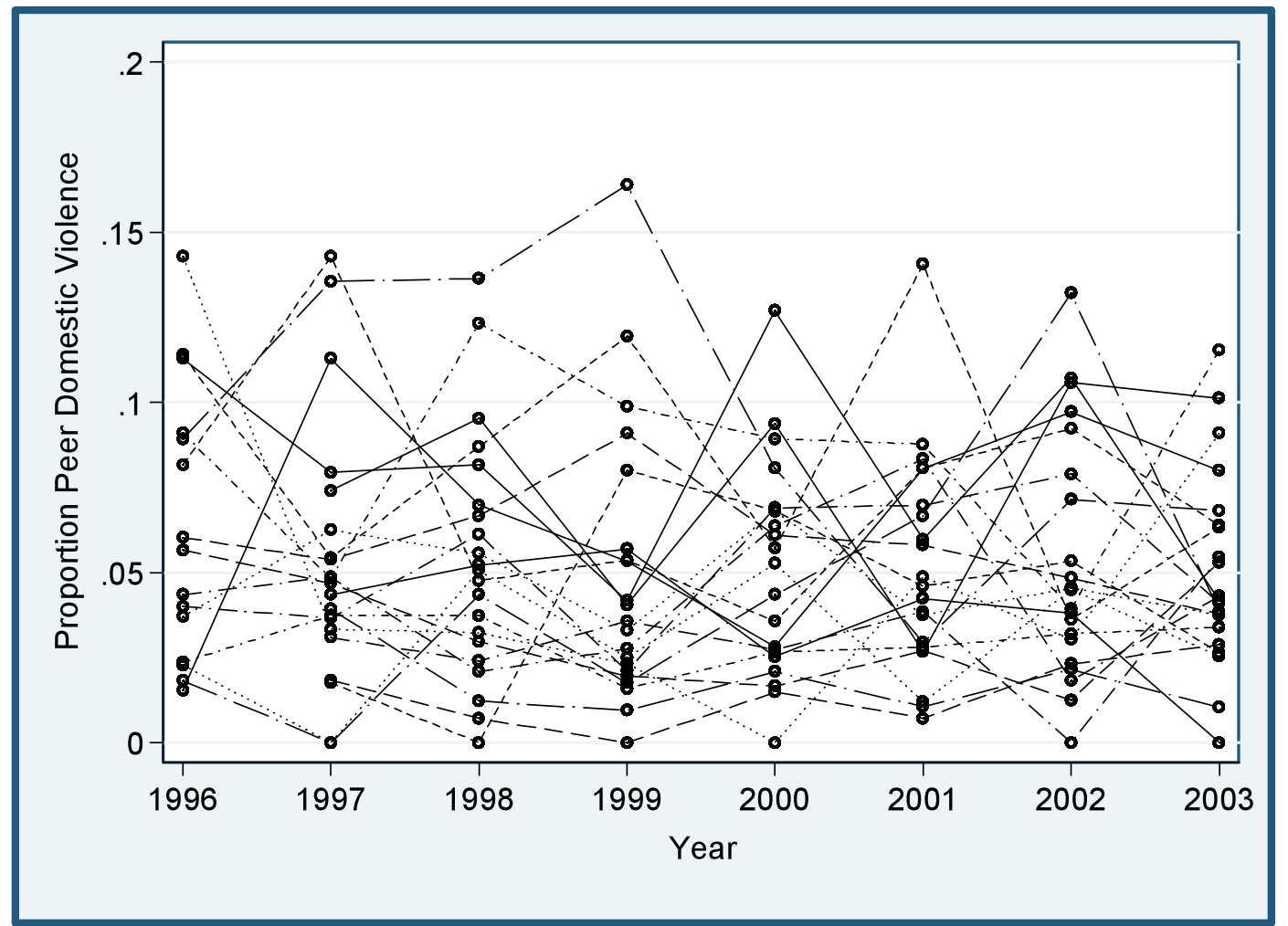

Figure 3: Proportion of $5^{\text {th }}$ Grade Peers from Families with Domestic Violence from 1996 to 2003 by School 
Table 1: Summary Statistics

\begin{tabular}{|c|c|c|c|c|c|c|}
\hline Variable & Subgroup & Obs & Mean & Std. Dev. & Min & $\operatorname{Max}$ \\
\hline \multicolumn{2}{|c|}{ 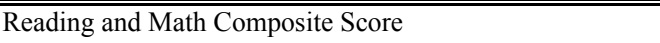 } & 42,478 & 52.9 & 29.0 & $\overline{1}$ & 99 \\
\hline & Subsidized Lunch & 22,674 & 39.7 & 26.1 & 1 & 99 \\
\hline & Unsubsidized Lunch & 19,804 & 68.0 & 24.5 & 1 & 99 \\
\hline & All Boys & 20,859 & 51.0 & 29.4 & 1 & 99 \\
\hline & All Girls & 21,619 & 54.8 & 28.5 & 1 & 99 \\
\hline & Boys Exposed to Domestic Violence & 957 & 36.6 & 25.0 & 1 & 99 \\
\hline & Girls Exposed to Domestic Violence & 980 & 40.8 & 26.5 & 1 & 98 \\
\hline \multicolumn{2}{|c|}{ Committed Disciplinary Infraction } & 44,882 & 0.18 & 0.39 & 0 & 1 \\
\hline & Subsidized Lunch & 23,870 & 0.28 & 0.45 & 0 & 1 \\
\hline & Unsubsidized Lunch & 21,012 & 0.08 & 0.27 & 0 & 1 \\
\hline & All Boys & 22,120 & 0.26 & 0.44 & 0 & 1 \\
\hline & All Girls & 22,762 & 0.11 & 0.32 & 0 & 1 \\
\hline & Boys Exposed to Domestic Violence & 1,039 & 0.43 & 0.49 & 0 & 1 \\
\hline & Girls Exposed to Domestic Violence & 1,040 & 0.19 & 0.39 & 0 & 1 \\
\hline \multicolumn{2}{|c|}{ Number of Disciplinary Incidents } & 44,882 & 0.56 & 1.92 & 0 & 44 \\
\hline & Subsidized Lunch & 23,870 & 0.92 & 2.46 & 0 & 44 \\
\hline & Unsubsidized Lunch & 21,012 & 0.16 & 0.83 & 0 & 25 \\
\hline & All Boys & 22,120 & 0.84 & 2.39 & 0 & 44 \\
\hline & All Girls & 22,762 & 0.29 & 1.26 & 0 & 34 \\
\hline & Boys Exposed to Domestic Violence & 1,039 & 1.77 & 3.68 & 0 & 37 \\
\hline & Girls Exposed to Domestic Violence & 1,040 & 0.53 & 1.63 & 0 & 21 \\
\hline \multirow[t]{7}{*}{ Ever Sus } & & 44,882 & 0.09 & 0.28 & 0 & 1 \\
\hline & Subsidized Lunch & 23,870 & 0.14 & 0.35 & 0 & 1 \\
\hline & Unsubsidized Lunch & 21,012 & 0.02 & 0.16 & 0 & 1 \\
\hline & All Boys & 22,120 & 0.13 & 0.33 & 0 & 1 \\
\hline & All Girls & 22,762 & 0.05 & 0.22 & 0 & 1 \\
\hline & Boys Exposed to Domestic Violence & 1,039 & 0.24 & 0.43 & 0 & 1 \\
\hline & Girls Exposed to Domestic Violence & 1,040 & 0.09 & 0.28 & 0 & 1 \\
\hline \multicolumn{2}{|r|}{ 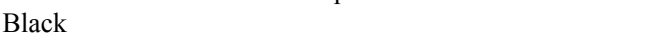 } & 44,882 & 0.38 & 0.48 & 0 & 1 \\
\hline \multicolumn{2}{|l|}{ Male } & 44,882 & 0.49 & 0.50 & 0 & 1 \\
\hline \multicolumn{2}{|c|}{ Free/Reduced Lunch } & 44,882 & 0.53 & 0.50 & 0 & 1 \\
\hline \multicolumn{2}{|c|}{ Exposed to Domestic Violence } & 44,882 & 0.046 & 0.210 & 0 & 1 \\
\hline \multicolumn{2}{|c|}{ Boys Exposed to Domestic Violence } & 44,882 & 0.023 & 0.150 & 0 & 1 \\
\hline \multicolumn{2}{|c|}{ Girls Exposed to Domestic Violence } & 44,882 & 0.023 & 0.150 & 0 & 1 \\
\hline \multicolumn{2}{|c|}{ Peer Domestic Violence } & 44,882 & 0.046 & 0.032 & 0 & 0 \\
\hline \multicolumn{2}{|c|}{ Peer Boy Domestic Violence } & 44,882 & 0.023 & 0.021 & 0 & 0.104 \\
\hline \multicolumn{2}{|c|}{ Peer Girl Domestic Violence } & 44,882 & 0.023 & 0.020 & 0 & 0.117 \\
\hline \multicolumn{2}{|c|}{ Cohort-Level Domestic Violence } & 514 & 0.051 & 0.034 & 0 & 0.164 \\
\hline \multicolumn{2}{|c|}{ Cohort-Level Boy Domestic Violence } & 514 & 0.026 & 0.023 & 0 & 0.106 \\
\hline \multicolumn{2}{|c|}{ Cohort-Level Girl Domestic Violence } & 514 & 0.025 & 0.022 & 0 & 0.115 \\
\hline \multicolumn{2}{|c|}{ Cohort-Level Median Family Zip Code Income } & 514 & $\$ 42,914$ & $\$ 8,825$ & $\$ 27,216$ & $\$ 60,667$ \\
\hline \multicolumn{2}{|c|}{ Cohort Size } & 514 & 87.30 & 32.70 & 23 & 222 \\
\hline
\end{tabular}

Notes: Cohort refers to a group of children in the same grade in the same sschool in the same year. 
Table 2: Family Violence Linear-in-Mean Peer Effects

\begin{tabular}{|c|c|c|c|c|}
\hline Specification & 1 & 2 & 3 & 4 \\
\hline \multirow[b]{2}{*}{ Outcome Variable } & Academic & \multicolumn{3}{|c|}{ Disciplinary } \\
\hline & $\begin{array}{l}\text { Reading and Math } \\
\text { Composite Score }\end{array}$ & $\begin{array}{l}\text { Commit } \\
\text { Infraction }\end{array}$ & $\begin{array}{l}\text { Number } \\
\text { Infractions }\end{array}$ & Suspended \\
\hline Own Family Violence & $\begin{array}{c}-3.85 * * * \\
(0.76)\end{array}$ & $\begin{array}{c}0.05^{* * * *} \\
(0.01)\end{array}$ & $\begin{array}{c}0.31^{* * *} \\
(0.08)\end{array}$ & $\begin{array}{c}0.04 * * * \\
(0.01)\end{array}$ \\
\hline Proportion Peers with Family Violence & $\begin{array}{c}-13.42 * \\
7.96\end{array}$ & $\begin{array}{l}0.22 * \\
(0.12)\end{array}$ & $\begin{array}{c}1.80 * * * \\
(0.70)\end{array}$ & $\begin{array}{c}0.13 \\
(0.09)\end{array}$ \\
\hline Observations & 42,478 & 44,882 & 44,882 & 44,882 \\
\hline School-Grade Fixed Effects & Yes & Yes & Yes & Yes \\
\hline School-Grade-specific linear time trends & Yes & Yes & Yes & Yes \\
\hline
\end{tabular}

Notes: Each column represents a different regression. Robust standard errors clustered at the school by cohort level are in parentheses. Asterisks *,**, and *** denote statistical significance at the $10 \%, 5 \%$, and $1 \%$ levels, respectively. All specifications control for gender, race, median family income, subsidized lunch status, and year fixed effects. 
Table 3: Differential Effects by Family Income

\begin{tabular}{|c|c|c|c|c|}
\hline Specification & 1 & 2 & 3 & 4 \\
\hline \multirow[b]{2}{*}{ Outcome Variable } & Academic & \multicolumn{3}{|c|}{ Disciplinary } \\
\hline & $\begin{array}{l}\text { Reading and Math } \\
\text { Composite Score }\end{array}$ & $\begin{array}{l}\text { Commit } \\
\text { Infraction }\end{array}$ & $\begin{array}{l}\text { Number } \\
\text { Infractions }\end{array}$ & Suspended \\
\hline Own Family Violence * Subsidized Lunch & $\begin{array}{c}-3.12 * * * \\
(0.76)\end{array}$ & $\begin{array}{c}0.05^{* * *} \\
(0.01)\end{array}$ & $\begin{array}{c}0.32^{* * * *} \\
(0.09)\end{array}$ & $\begin{array}{c}0.04 * * * \\
(0.01)\end{array}$ \\
\hline Own Family Violence * No Subsidized Lunch & $\begin{array}{c}-7.55 * * * \\
(1.93)\end{array}$ & $\begin{array}{r}0.05 * * \\
(0.02)\end{array}$ & $\begin{array}{l}0.26^{* *} \\
(0.11)\end{array}$ & $\begin{array}{l}0.03^{*} \\
(0.02)\end{array}$ \\
\hline Peer Family Violence * Subsidized Lunch & $\begin{array}{l}-7.43 \\
(9.06)\end{array}$ & $\begin{array}{c}0.35^{* *} \\
(0.16)\end{array}$ & $\begin{array}{l}2.43 * * \\
(0.95)\end{array}$ & $\begin{array}{l}0.20^{*} \\
(0.12)\end{array}$ \\
\hline Peer Family Violence * Unsubsidized Lunch & $\begin{array}{c}-24.85^{* *} \\
(12.13)\end{array}$ & $\begin{array}{l}-0.03 \\
(0.15)\end{array}$ & $\begin{array}{c}0.56 \\
(0.77)\end{array}$ & $\begin{array}{l}-0.02 \\
(0.10)\end{array}$ \\
\hline Observations & 42,478 & 44,882 & 44,882 & 44,882 \\
\hline School-Grade Fixed Effects & Yes & Yes & Yes & Yes \\
\hline School-Grade-specific linear time trends & Yes & Yes & Yes & Yes \\
\hline
\end{tabular}

Notes: Each column represents a different regression. Robust standard errors clustered at the school by cohort level are in parentheses. Asterisks *,**, and *** denote statistical significance at the $10 \%, 5 \%$, and $1 \%$ levels, respectively. All specifications control for gender, race, median family income, subsidized lunch status, and year fixed effects. 
Table 4: Differential Effects by Gender and Race

\begin{tabular}{|c|c|c|c|c|}
\hline Specification & 1 & 2 & 3 & 4 \\
\hline \multirow[b]{2}{*}{ Outcome Variable } & Academic & \multicolumn{3}{|c|}{ Disciplinary } \\
\hline & $\begin{array}{l}\text { Reading and Math } \\
\text { Composite Score }\end{array}$ & $\begin{array}{l}\text { Commit } \\
\text { Infraction }\end{array}$ & $\begin{array}{l}\text { Number } \\
\text { Infractions }\end{array}$ & Suspended \\
\hline Own White Boy Family Violence & $\begin{array}{c}-5.73^{* * *} \\
(1.91)\end{array}$ & $\begin{array}{c}0.11^{* * *} \\
0.03\end{array}$ & $\begin{array}{c}0.44^{* * *} \\
0.15\end{array}$ & $\begin{array}{c}0.07^{* * * *} \\
0.02\end{array}$ \\
\hline Own Black Boy Family Violence & $\begin{array}{l}-2.06^{*} \\
(1.19)\end{array}$ & $\begin{array}{c}0.06^{* * * *} \\
0.02\end{array}$ & $\begin{array}{c}0.65^{* * *} \\
0.21\end{array}$ & $\begin{array}{c}0.06^{* * *} \\
0.02\end{array}$ \\
\hline Own White Girl Family Violence & $\begin{array}{c}-6.14 * * * \\
(2.01)\end{array}$ & $\begin{array}{c}-0.02 \\
0.02\end{array}$ & $\begin{array}{c}-0.11 * * \\
0.04\end{array}$ & $\begin{array}{c}-0.01 \\
0.01\end{array}$ \\
\hline Own Black Girl Family Violence & $\begin{array}{l}-2.81 * * \\
(1.17)\end{array}$ & $\begin{array}{c}0.04 * * \\
0.02\end{array}$ & $\begin{array}{c}0.14^{*} \\
0.08\end{array}$ & $\begin{array}{l}0.02 \\
0.01\end{array}$ \\
\hline Peer Family Violence * White * Boy & $\begin{array}{c}-31.64 * * \\
(13.13)\end{array}$ & $\begin{array}{c}0.35^{* *} \\
0.17\end{array}$ & $\begin{array}{l}2.50 * * * \\
0.82\end{array}$ & $\begin{array}{c}0.31 * * \\
0.13\end{array}$ \\
\hline Peer Family Violence * Black * Boy & $\begin{array}{l}-17.56 \\
(13.03)\end{array}$ & $\begin{array}{l}0.28 \\
0.28\end{array}$ & $\begin{array}{l}1.90 \\
1.94\end{array}$ & $\begin{array}{l}0.13 \\
0.21\end{array}$ \\
\hline Peer Family Violence * White * Girl & $\begin{array}{c}4.30 \\
(11.93)\end{array}$ & $\begin{array}{c}-0.20 \\
0.19\end{array}$ & $\begin{array}{l}-0.32 \\
0.85\end{array}$ & $\begin{array}{c}-0.24 * * \\
0.11\end{array}$ \\
\hline Peer Family Violence * Black* Girl & $\begin{array}{c}-9.02 \\
(12.50)\end{array}$ & $\begin{array}{c}0.43 * * \\
0.20\end{array}$ & $\begin{array}{c}3.05^{* * *} \\
1.06\end{array}$ & $\begin{array}{c}0.30 * * \\
0.15\end{array}$ \\
\hline$\overline{\text { Observation }}$ & 42,478 & 44,882 & 44,882 & 44,882 \\
\hline School-Grade Fixed Effects & Yes & Yes & Yes & Yes \\
\hline School-Grade-specific linear time trends & Yes & Yes & Yes & Yes \\
\hline
\end{tabular}

Notes: Each column represents a different regression. Robust standard errors clustered at the school by cohort level are in parentheses. Asterisks *,**, and *** denote statistical significance at the $10 \%, 5 \%$, and $1 \%$ levels, respectively. All specifications control for gender, race, median family income, subsidized lunch status, and year fixed effects. 
Table 5: Differential Effects by Gender of the Troubled Peer

\begin{tabular}{|c|c|c|c|c|}
\hline Specification & 1 & 2 & 3 & 4 \\
\hline \multirow[b]{2}{*}{ Outcome Variable } & Academic & \multicolumn{3}{|c|}{ Disciplinary } \\
\hline & $\begin{array}{l}\text { Reading and Math } \\
\text { Composite Score }\end{array}$ & $\begin{array}{l}\text { Commit } \\
\text { Infraction }\end{array}$ & $\begin{array}{l}\text { Number } \\
\text { Infractions }\end{array}$ & Suspended \\
\hline Own Boy Family Violence & $\begin{array}{c}-3.54 * * * \\
1.01\end{array}$ & $\begin{array}{l}0.09^{* * *} \\
0.02\end{array}$ & $\begin{array}{c}0.63^{* * *} \\
0.15\end{array}$ & $\begin{array}{c}0.07 * * * \\
0.02\end{array}$ \\
\hline Own Girl Family Violence & $\begin{array}{c}-4.10^{* * *} \\
1.1\end{array}$ & $\begin{array}{l}0.01 \\
0.01\end{array}$ & $\begin{array}{l}-0.02 \\
0.05\end{array}$ & $\begin{array}{c}-0.001 \\
0.01\end{array}$ \\
\hline Proportion of Boy Peers with Family Violence * Boy & $\begin{array}{c}-38.34 * * * \\
13.68\end{array}$ & $\begin{array}{l}0.87 * * * \\
0.23\end{array}$ & $\begin{array}{c}6.46^{* * *} \\
1.36\end{array}$ & $\begin{array}{c}0.65 * * * \\
0.18\end{array}$ \\
\hline Proportion of Girl Peers with Family Violence * Boy & $\begin{array}{c}3.27 \\
11.88\end{array}$ & $\begin{array}{c}-0.11 \\
0.21\end{array}$ & $\begin{array}{l}0.55 \\
1.02\end{array}$ & $\begin{array}{l}0.01 \\
0.15\end{array}$ \\
\hline Proportion of Boy Peers with Family Violence * Girl & $\begin{array}{c}-10.44 \\
13.33\end{array}$ & $\begin{array}{l}0.05 \\
0.24\end{array}$ & $\begin{array}{l}0.46 \\
1.33\end{array}$ & $\begin{array}{l}0.07 \\
0.18\end{array}$ \\
\hline Proportion of Girl Peers with Family Violence * Girl & $\begin{array}{l}-8.85 \\
12.39\end{array}$ & $\begin{array}{l}0.06 \\
0.18\end{array}$ & $\begin{array}{l}-0.4 \\
1.03\end{array}$ & $\begin{array}{c}-0.25^{*} \\
0.14\end{array}$ \\
\hline Observations & 42,478 & 44,882 & 44,882 & 44,882 \\
\hline School-Grade Fixed Effects & Yes & Yes & Yes & Yes \\
\hline School-Grade-specific linear time trends & Yes & Yes & Yes & Yes \\
\hline
\end{tabular}

Notes: Each column represents a different regression. Robust standard errors clustered at the school by cohort level are in parentheses. Asterisks *,**, and *** denote statistical significance at the $10 \%, 5 \%$, and $1 \%$ levels, respectively. All specifications control for gender, race, median family income, subsidized lunch status, and year fixed effects. 
Table 6: Robustness Checks

A. Includes Only Students with Siblings in the Sample

\begin{tabular}{|c|c|c|c|c|}
\hline \multirow[b]{3}{*}{ Outcome Variable } & 1 & 2 & 3 & 4 \\
\hline & Academic & \multicolumn{3}{|c|}{ Disciplinary } \\
\hline & $\begin{array}{l}\text { Reading and Math } \\
\text { Composite Score }\end{array}$ & $\begin{array}{c}\text { Commit } \\
\text { Infraction }\end{array}$ & $\begin{array}{c}\text { Number } \\
\text { Infractions }\end{array}$ & Suspended \\
\hline Proportion of Boy Peers with Family Violence * Boy & $\begin{array}{c}-40.15 * * * \\
15.14\end{array}$ & $\begin{array}{c}1.03 * * * \\
0.27\end{array}$ & $\begin{array}{c}6.62 * * * \\
1.84\end{array}$ & $\begin{array}{c}0.63 * * * \\
0.2\end{array}$ \\
\hline Observations & 26,922 & 28,597 & 28,597 & 28,597 \\
\hline
\end{tabular}

B. Includes Sibling Fixed Effects

\begin{tabular}{|c|c|c|c|c|}
\hline & & & & \\
\hline & 1 & 2 & 3 & 4 \\
\hline \multirow[b]{2}{*}{ Outcome Variable } & Academic & \multicolumn{3}{|c|}{ Disciplinary } \\
\hline & $\begin{array}{l}\text { Reading and Math } \\
\text { Composite Score }\end{array}$ & $\begin{array}{c}\text { Commit } \\
\text { Infraction }\end{array}$ & $\begin{array}{c}\text { Number } \\
\text { Infractions }\end{array}$ & Suspended \\
\hline \multirow{2}{*}{ Proportion of Boy Peers with Family Violence * Boy } & $-26.90 * *$ & $0.50 *$ & $4.85 * * *$ & $0.40 * *$ \\
\hline & 12.32 & 0.26 & 1.48 & 0.18 \\
\hline Observations & 26,922 & 28,597 & 28,597 & 28,597 \\
\hline
\end{tabular}

C. Includes Controls for Cohort Race, Gender, subsidized lunch, and zip code income

\begin{tabular}{|c|c|c|c|c|}
\hline \multirow[b]{3}{*}{ Outcome Variable } & 1 & 2 & 3 & 4 \\
\hline & Academic & \multicolumn{3}{|c|}{ Disciplinary } \\
\hline & $\begin{array}{l}\text { Reading and Math } \\
\text { Composite Score }\end{array}$ & $\begin{array}{c}\text { Commit } \\
\text { Infraction }\end{array}$ & $\begin{array}{c}\text { Number } \\
\text { Infractions }\end{array}$ & Suspended \\
\hline Proportion of Boy Peers with Family Violence * Boy & $\begin{array}{c}-37.08^{* * *} \\
13.66 \\
\end{array}$ & $\begin{array}{c}0.86^{* * *} \\
0.22 \\
\end{array}$ & $\begin{array}{c}6.32 * * * \\
1.37 \\
\end{array}$ & $\begin{array}{c}0.65^{* * *} \\
0.17 \\
\end{array}$ \\
\hline Observations & 42,478 & 44,882 & 44,882 & 44,882 \\
\hline
\end{tabular}

Notes: Each column represents a different regression. Robust standard errors clustered at the school by cohort level are in parentheses. Asterisks *,**, and *** denote statistical significance at the $10 \%, 5 \%$, and $1 \%$ levels, respectively. All specifications control for gender, race, median family income, subsidized lunch status, and year fixed effects. 
Table 7: Falsification Tests: The Effect of Peer Family Violence on Exogenous Student Characteristics

\begin{tabular}{lccccc}
\hline \hline Outcome Variable & 1 & 2 & 3 & 4 & 5 \\
\hline Proportion of Boy Peers with Family Violence & -8.21 & 0.07 & -0.001 & 0.07 & $\begin{array}{c}\text { Log Median } \\
\text { Zip Code } \\
\text { Income }\end{array}$ \\
& $(30.70)$ & 0.12 & $(0.15)$ & $(0.19)$ & -0.10 \\
Proportion of Girl Peers with Family Violence & -7.99 & -0.17 & -0.03 & -0.03 & -0.07 \\
\hline Observations & $(35.83)$ & 0.13 & 0.2 & 0.21 & 0.08 \\
School-Grade Fixed Effects & 514 & 44,882 & 44,882 & 44,882 & 44,454 \\
School-Grade-specific linear time trends & Yes & Yes & Yes & Yes & Yes \\
\hline
\end{tabular}

Notes: Each column represents a different regression. Robust standard errors clustered at the schooo by cohort level are in parentheses. Asterisks ***, and *** denote statistical significance at the $10 \%, 5 \%$, and $1 \%$ levels, respectively. All specifications control for gender, race, median family income, subsidized lunch status, and year fixed effects. Data for Specification 1 is collapsed at the school-grade-year level. 